\title{
In Irons
}


This page intentionally left blank 


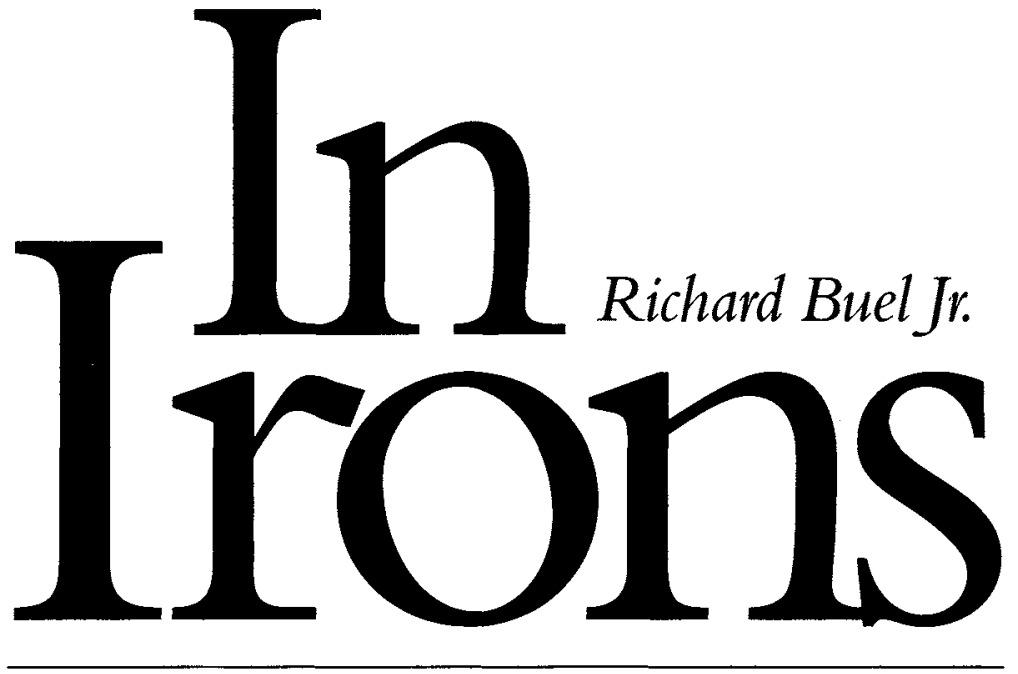

Britain's Naval Supremacy and the American Revolutionary Economy 
Published with assistance from

the Annie Burr Lewis Fund.

Copyright (C) I 998 by Yale University.

All rights reserved.

This book may not be reproduced, in whole or in part, including illustrations, in any form (beyond that copying permitted by Sections 107 and 108 of the

U.S. Copyright Law and except by reviewers for the public press), without written permission from the publishers.

Printed in the United States of America

Library of Congress Cataloging-in-Publication Data Buel, Richard, I933-

In irons : Britain's naval supremacy and the American

Revolutionary economy / Richard Buel, Jr.

p. $\mathrm{cm}$.

Includes bibliographical references and index.

ISBN 0-300-07388-7 (alk. paper)

I. United States-History-Revolution, I775-I783-

Finance. 2. United States-History-Revolution, I775-I783-Naval operations, British. 3. United

States-Commerce-History-I 8 th century.

4. Agriculture-Economic aspects-United States-

History-I 8 th century. 5. Great Britain, Royal

Navy-History-Revolution, I775-1783. I. Title.

$$
\begin{array}{rl}
\mathrm{E}_{21} \mathrm{5.B8} 84 & \mathrm{I} 998 \\
972.3^{\prime} \mathrm{I}-\mathrm{dc2I} & 98-2 \mathrm{I} 28 \mathrm{I} \\
& \mathrm{CIP}
\end{array}
$$

A catalogue record for this book is available from the British Library.

The paper in this book meets the guidelines for permanence and durability of the Committee on Production Guidelines for Book Longevity of the Council on Library Resources. 
For Marilyn 
This page intentionally left blank 